\title{
COMPARATIVE ECONOMIC DEVELOPMENT MODELS POLAND AND THE REPUBLIC OF KOREA
}

\author{
Lukasz GOLOTA, PhD
}

Faculty of Political Science and International Studies, University of Warsaw, Poland

1.golota@uw.edu.pl

\begin{abstract}
Poland and South Korea are widely recognised as successful examples of economic transformation. As a result of transformation, poor and economically underdeveloped states have managed to maintain extraordinary economic growth for a long time, significantly improving their citizens' quality of life and joining the group of highly developed economies. The changes in both states were implemented on the basis of consistent references to two different paradigms of political economy: interventionist and liberal. This article presents theoretical models of growth, trying to match them with the practical dimension of the economic policy of the two states. The aim of the comparison is to define and present these models and their empirical verification. The period of the study in the case of South Korea comprises mainly the developments after 1961, and in the case of Poland, the reforms after 1989. The article consists of five sections dealing, respectively, with: theoretical aspects of development; justification of the comparison and the choices made by the states; transformation in South Korea; transformation in Poland; and finally, the summary.
\end{abstract}

Keywords: Economic development models, growth, economic policy, economic transformation, Poland, South Korea.

\section{Theoretical aspects of economic development and growth}

The aim of this article is to compare the economic development models of two economic transformations that are widely recognised as successful. They constitute the two cases frequently referred to not only in the scientific literature, but also in real reform programmes designed for the so-called economies in transition. The comparative research approach will allow for a more comprehensive presentation of the course of the changes and will also allow attention to be paid to elements that may otherwise remain hidden. The aim of the study is also to define what the 
developmental models adopted by Poland and South Korea were based on (Cypher and Dietz, 1997).

Since the formation by Xenophon of the term oikonomics, the ambition of the majority of economics scholars has been not only to familiarise themselves with its phenomena and laws, but also to formulate principles that might become a universal model for achieving prosperity. By creating principles, formulating recommendations and guidelines, some of them abandoned the positivist narration of scientific research and transformed economics into a more normative science. ${ }^{1}$ More or less theoretical, idealistic or materialistic, utopian or scientific visions of development laws were created. Some of them have been very strictly verified and evaluated by history. The empirically verifiable cases seem to be more valuable. Representatives of this principles-focussed approach are represented in nearly all eras - Xenophobe, Aristotle, Saint Thomas, J.B. Colbert, T. Mun, A. Smith, D. Ricardo, J.S. Mill, K. Marx, L. V. Mises, J.M. Keynes, J. V. Hayek, J. Willamson, J. Stiglitz and many others.

The starting point for this study will be the question regarding the definition of the development model, understood as a set of economic assumptions based on a coherent economic paradigm. These models do not involve just economics, that is, their area of influence goes far beyond the boundaries of economics. Their implementation has brought specific results: higher than average economic growth, an increase in standard of living, changes in the structure of national income production, profound social and even cultural transformations.

Navigating the theoretical forms of growth should begin with a direct reference to the theory of development, which assumes that less developed countries differ from developed countries. They are different and should be treated differently. Thanks to this statement by Robert Gilpin, one may set the hypothesis that while neoclassical (neoliberal) principles work well in highly developed economies, specific conditions in developing countries make them inapplicable (Gilpin, 2001, p 307).

What is more, countries that have undergone industrialisation processes earlier, using the 'Advantage of competition's backwardness', were able to exploit production and purchase factors more effectively, which gave them a significant advantage and experience. Currently, developing

\footnotetext{
${ }^{1}$ Such an approach is found in the works of most of the representatives of the classical school in economics, including A. Smith, D. Ricardo, R. Maltus, J.B.Say, J. S. Mill. The aim of their dissertations is not only to present the laws of economics, but to formulate the principles of economic policy for governments.
} 
countries operate in the international environment with very strong competition and have no chance to catch up with the developed countries without state intervention (Gerschenkron, 1962). Raul Prebisch, ${ }^{2}$ UNCTAD and Economic Commission for Latin America expert, argued that in such conditions, developing countries should build economic structures behind the high wall of customs protection (Gilpin, 2001, p 308).

Gunnar Myrdal also drew attention to the impossibility of self-reliant escape from the closed economic circle of poverty. He explains that poor countries have low levels of savings, which translate into low capital expenditure.This means that their enterprises do not have the resources necessary for development and cannot compete, thus remaining out of the international market - which pushes the country into poverty and even lower savings rate (Myrdal, 1957). Only state institutions - not market mechanisms - allow poor countries to break free from this circle. This theory was also presented as the 'Big Push' strategy by Paul Rosenstein-Rodan (1943). Robert Wade used the term 'governed market' to illustrate economic mechanisms based on the theory of development in developed countries (Wade, 2003).

The essence of the model based on the theory of development boils down to the recognition that the market mechanisms themselves, in conditions of economic underdevelopment, will not ensure effective allocation of production factors. Only state intervention in the form of industrial policies, including trade policies, will allow elimination of economic dysfunctions and generate positive incentives within the economy (Wziątek-Kubiak, 1996, pp. 106, 107). This is the interventionist model. Its essence is the recognition of the necessity of state participation in the economy and in the international market - recognition of the legitimacy of protecting national markets. It aims at mitigating the effects of liberalisation for low-competitive domestic production, reducing the distorting impact of the international environment and giving time to adapt production branches to the global level. In contrast to the liberal approach which allows shock therapy, protectionist policy is of a long-term nature Wziątek-Kubiak, 1996, p. 108).

Liberalism, in turn, embodies the belief of the classical school in the concept of the invisible hand of the market, the private initiative of the Austrian school or the positive effect of

\footnotetext{
2 See A. Wróbel (2005) Paula Prebischa wizja gospodarki światowej i jego rola w rozwoju teorii wymiany międzynarodowej (Paul Prebisch's vision of the global economy and its role in the development of international exchange theory). In: R. Kuźniar (eds.) Porządek międzynarodowy u progu XXI wieku. Wizje, koncepcje, paradygmaty (International order at the beginning of the 21st century-Visions, concepts, paradigms), Uniwersytet Warzawski, Warszawa.
} 
Schumpeter's creative destruction. ${ }^{3}$ It is based on the neoclassical price theory, standard macroeconomics and the concept of homo oeconomicus (Piątek and Szarzec, 2008). In the international dimension, it is in the nature of liberalism to pursue trade policies based on the promotion of exports, and not the anti-import or autarkic policies.

It should be remembered that the creators of the Washington consensus - the symbol of neoliberalism - considered their programme to be fully universal, that is, one that was effective in any place and time. The degree of development of a state, its social capital or cultural circle to which it belonged were not considered of significance. Apologists of neoliberalism recommended, sometimes even enforced, the application of its principles at every opportunity. Changes in Korea, on the other hand, were of deterministic nature as existing conditions were taken into accountcurrent needs and real opportunities (Gołota, 2016). Liberalism allows evolutionary, natural changes in the institutions of the capitalist market and includes opposition to the 'constructivist' reforms introduced by a state, which distort natural economic processes. In the methodological dimension, the liberal paradigm tries to explain the economic reality with the aid of abstract models popularised by Paul Samuelson in his work Foundations of Economic Analysis (Samuelson, 1983). This methodological shift from descriptive research to a very formal one has undermined interest in the theory of development. In times of growing interest in mathematical and formal methods, it could not be presented in the form of abstract modelling (Krugman, 1995).

It is also useful at this stage to refer briefly to the postulates regarding the method of introducing changes: that is, the theory of shock therapy (usually associated with neoliberalism) and gradualist therapy (associated with systematic state activity in the economy). The first one assumes that the broadest possible, comprehensive reform effort must be undertaken within the shortest possible time as the political mandate for its implementation, may quickly dwindle as a result of social unrest. It should be noted that partial reforms in socialist countries did not bring any results, so it may be that only 'shock' solutions show results. An example is price liberalisation in Poland, which without any institutional, legal, or regulatory changes would not make sense.

\footnotetext{
${ }^{3}$ Ben Slay (1993) The Dilemmas of Economic Liberalism in Poland, Europe-Asia Studies, No.2, p. 238. Joseph Schumpeter observed that the emergence of new, innovative enterprises is usually accompanied by the collapse of older and more traditional ones. This process sustains economic development and is a positive phenomenon (creative destruction). An example can be Xerox (photocopiers) or Polaroid (cameras) which, after the technological revolution in their industry, stopped developing and were consumed by competition.
} 
Therefore, the change should be radical, carried out at once, and at the beginning of the transformation (Jarmołowicz and Piątek, 2016). The second method assumes the changes are amortised over time.

It is in this case that the policy of creating industry 'from scratch' — which, in the conditions of global competition, would not have a chance of success-is important. This issue was first noticed in the $19^{\text {th }}$ century in the theory of trade by John Stuart Mill (1959, p. 749), who allowed the possibility of protection in the cases of, as he called it, the 'infant industry'. He thus opposed the achievements of the classical school in the area of international exchange. He recognised that the entry barrier for new players in the market, in the conditions of the liberal economic order, dominated by huge players, would be impossible to overcome. ${ }^{4}$

The recognition of the role of trade in the transformation process is crucial. In fact, a since David Ricardo's theory of comparative advantage, international trade has been perceived as an instrument of economic development (Ricardo, 2004). Although the naive belief in equal distribution of benefits in the course of trade exchange was abandoned (Gołota, 2016), trade is still widely recognised as an instrument conducive to economic development. The best example of that is the universality of the WTO system and the universality of free trade agreements (currently 445 RTA - Regional Trade Agreements -notifications have been sent to WTO). ${ }^{5}$ The same refers to the international flow of investments, which is widely recognised as having a positive impact on economic development (Weidenbaum, 1969). The trade-based approach will therefore be a litmus test in determining the relevant theory-neoliberalism or interventionism.

The interest in the mechanisms of achieving growth led to the formation of (political) development economics as a separate branch of economics. Researchers in this area are also classified on the basis of two basic issues: the impact of external factors on economic development and the role of the state in the economy (O'Brien, M. Williams, 2013, p. 223). Walt Rostow (1960), in his book The Stages of Economic Growth, indicates that each society, regardless of the environment, undergoes the same stages of development. Thus, following the solutions provided by developed economies will allow faster development (modernisation theory). Yet, researchers such as Theotonito Dos Santos (1970), Andre Frank (1967) and Samir Amin (1976) argue that

\footnotetext{
${ }^{4}$ For example, it seems impossible to create a Polish car in the current conditions of global competition without state support.

${ }^{5}$ https://www.wto.org/english/tratop_e/region_e/regfac_e.htm [accessed 28.11.2017].
} 
development differences have arisen as a result of external factors: mutual influence and often economic exploitation. In their opinion, development disparities would not have appeared without the global capitalist system. Thus, they emphasise the dominance of external factors.

The theories about economic growth discussed here have certain overlapping features and others that are exclusive to each. The purpose of Table 1 is to enable partial categorization.

Table 1: Selected opposing approaches in development economics. Own study.

\begin{tabular}{|c|c|c|}
\hline Indicator & Approach 1 & \multirow{2}{*}{$\begin{array}{l}\text { Approach } 2 \\
\text { Gradualism }\end{array}$} \\
\hline Time & Shock therapy & \\
\hline Internal/external & Modernisation theory & Interdependence \\
\hline factors' influence & $\begin{array}{l}\text { (repeatable internal } \\
\text { evolution,) }\end{array}$ & $\begin{array}{l}\text { theory } \\
\text { (the influence of the } \\
\text { environment, the ability to } \\
\text { shape) }\end{array}$ \\
\hline $\begin{array}{l}\text { Conditions (level of } \\
\text { development, culture etc.) }\end{array}$ & $\begin{array}{l}\text { Structural approach } \\
\text { (do not have impact) }\end{array}$ & $\begin{array}{l}\text { Deterministic } \\
\text { approach } \\
\text { (have impact) }\end{array}$ \\
\hline $\begin{array}{l}\text { States' role in } \\
\text { economy }\end{array}$ & Liberalism & Interventionism \\
\hline Approach to trade & Free trade & $\begin{array}{l}\text { Protectionism } \\
\text { (including infant } \\
\text { industry) }\end{array}$ \\
\hline
\end{tabular}

In relation to the structuralism/determinism division, the case of Korea was also of interest to Daron Acemoglu and James Robinson. They wondered why, despite the geographical, cultural and religious similarities, following the division in 1953, there occurred huge disparities in development. The two scholars recognise the interdependence of economic and political institutions as the key factor (Acemoglu, 2008). The publication of Joseph Stiglitz and Brad 
Greenwald (2015) sheds some light on Korea's development - the differences in the standard of living between countries are no longer determined by the differences in capital accumulation, but in technology and knowledge. On the one hand, they invoke examples of state policy in the field of trade and industry that can help create a learning society developing new technologies. On the other hand, they mention those which may delay the process of 'learning' (e.g., badly created system of intellectual property protection). They criticise state policies, especially those related to the neoliberal doctrine, proving that certain kinds of policies make it difficult for countries to acquire knowledge.

The dissertation of Jagdish Bhagwati and Arvind Panagariya (2013), using examples of transformation in India, promotes the importance of the liberalisation processes for economic development (including reference to the neoliberal model) and calls for further reforms, presenting solutions adopted in India as a model for other countries. ${ }^{6}$

Dani Rodrik (2015), recognizing that economic models treat economics as a science, warns against their uncritical referencing and use. He explains that models explain only a fraction of reality, and their proper selection depends on the circumstances. Therefore, they represent the deterministic attitude.

Bearing in mind the historical and contemporary debate on development theories, it is worth asking a few questions: Why have Poland and South Korea been selected and compared? In view of the differences between them, is such a comparison justified? Have any of the models shown more effective applications?

\section{Poland and South Korea-justification for the comparison}

Examples of economic transformation of Poland and South Korea are very symptomatic of the theoretical developmental models on which they were based. Although both models are based on similar values and economic assumptions (free market, private ownership), there is an essential difference between them - the role of the state in the allocation of production factors. The transformation processes carried out are, therefore, representative for the economic paradigms on which they were founded.

\footnotetext{
${ }^{6}$ On the socio-economic reforms in India, see: J. Zajączkowski, J. Schöttli, M. Thapa (2016) India in the Contemporary World: Polity, Economy and International Relations, New Delhi.
} 
In the case of Poland, there was a liberal model (market-capitalism), whose program document is the Washington Consensus. The (neo)liberal economic doctrine stems from the principles of classical economics, the views of neoclassical economists and the assumptions of the Chicago school of monetarism presented by John Williamson (1990) in the form of the famous 10 points. This is a structural approach, referring predominantly to the theory of modernisation and shock therapy.

In the case of Korea, reference should be made to the theory of development state, ${ }^{7}$ identified with the term state capitalism (Johnson, 1982), in which the central role of the state in the development processes (interventionism) is assumed. In the case of Asian countries, the terms 'South Consensus' or the 'East Asian model' are also used. This approach is based on the deterministic attitude. The best known economic interpretations of Asian models examined with the application of the developmental state concept include those by Alice Amsden (1989) and Robert Wade (1990).

First, one should note the basic differences between Poland and South Korea. While the subject of analysis in Korea constitutes the 'idea' of development taking place in post-war conditions, in the case of Poland, there is a systemic transformation involving a historical departure from the model of a centrally planned socialist economy to capitalist free market solutions. Second, the development of both countries happened during different historical periods. While the Korean economy was developing in the conditions of the Cold War and economic disintegration, Poland shaped its development in the conditions of dynamic globalisation, unprecedented economic liberalisation and advanced integration processes. The period of Korean prosperity coincides with historical events that have had an impact on the economy, such as the normalisation of relations with Japan or American economic aid.

Third, it should be remembered that the Korean transformation has been taking place since 1961; meanwhile, Poland has been building its prosperity based on new ideas since 1989 only. So, Korea is almost 30 years ahead of Poland. This is particularly important from the point of view of high-tech solutions being implemented by Korean industry, which development has happened in the last period of the Korean transformation and is practically contemporary to us. In the case of

\footnotetext{
${ }^{7}$ In this system development is based not only on market forces, but there is also considerable state involvement in the economy.
} 
Poland, this phase has not yet been reached. In Poland, over time, the doctrinal neoliberal approach was abandoned in favour of the adaptation policy, which reflected a more pragmatic character. In Korea, the study observes changes over a longer period of time (gradualism). For Poland, the study focuses on explaining the transformation itself (shock therapy). The economic processes that followed were a derivative of it, and politicians did not have much influence.

Fourth, both countries are very different culturally, which has a fundamental impact on social relations, the concept of the individual, as well as the role of the state in the economy. European liberalism, utilitarianism and formal egalitarianism should be contrasted against Asian hierarchy and collectivist values. For Europeans, the behaviour of Koreans during the 1997 crisis - giving their private gold to the central bank to save the national currency -is not understandable. ${ }^{8}$ The occurrence of such a phenomenon in the Western cultural scenario seems almost impossible.

Fifth, the changes in Korea were carried out under the conditions of the autocratic political system created by General Park. Meanwhile, the Polish economy was being reformed in the period of full democratisation. This is of key importance for politicians (constantly striving for public support) making economic decisions.

The question that arises is whether it is even possible to compare such vastly divergent countries. To answer it the common elements in the development of the two countries need to be identified: Firstly, they have both grown from situations of widespread poverty to highly developed economies. Both started with initial capital (experience, technology, lack of accumulated capital), had a similar production structure (primarily agricultural), and had a similar population potential. Both Poland and Korea experienced periods of partitions/occupation and wars in various historical periods.

Secondly, bearing in mind the above reservations, we may formulate the hypothesis that the examples of these two countries are not only characteristic of two developmental visions, but allow their empirical verification, and analysis of their merits and weaknesses. Eliminating the variables that distort the study will allow for obtaining a clear picture and for drawing conclusions.

\footnotetext{
${ }^{8}$ See Koreans give up their gold to help their country, BBC News 14 January 1998, [Online] Available from: http://news.bbc.co.uk/2/hi/world/analysis/47496.stm [accessed 28.11.2017].
} 


\section{Economic Transformation of the Republic of Korea}

The great economic transformation of the 1960s took place as a direct result of the conditions of a quite well-developed agricultural sector (i.e. after the first phase of the economic revolution) and can be understood in the context of Korea's own history. As Kenneth Kang and Vijaya Ramachandran argue, presenting the development of Korea as a great post-war phenomenon of the 1960s and 1970s is an incomplete approach, because the development would not have taken place if not for the conditions created by investments in the agricultural sector dating back to the time of Japanese colonisation (1910-1940). According to the plans of imperial Japan, Korea was to remain an integral part of the empire. Shortages in the agri-food market (resulting, for instance, in the unrest among residents in Japanese cities in 1918) convinced the Japanese of the need to make necessary investments in the agricultural sector in its overseas territories.

The Rice Production Development Program in Korea included construction of irrigation systems, increasing the areas of rice cultivation and introduction of fertilisers. The areas of cultivation covered by irrigation increased 16 times and agricultural production in 1928-1937 increased by $40 \%$. Investment in agriculture was accompanied by the construction of transport infrastructure and the entire programme was considered successful (Kang and. Ramachandran, 1999). Thus, the foundation of an efficient, agronomic production system was created.

However, after the civil war in the early 1960s, South Korea belonged to the group of the poorest countries in the world, where the gross income per capita was USD 80 (Clifford, 1998, p.9). The most important production sector was agriculture. This country, destroyed by military actions of World War II and the devastating civil war, was at times entirely dependent on international humanitarian aid. Then in 1961, the military coup d'état by General Park Chung-hee (1917-1979) took place. The new leader of Korea was characterised by unusual pragmatism. He did not hesitate to rebuild diplomatic relations with the hated enemy-Japan - in order to raise capital after reducing US aid during the Kennedy presidency.

Japan willingly responded to Park's gesture by awarding large loans (USD 800 million) and transferring some of its production activity to Korea (Kightley, 2013, p. 81). It was also ready to send Korean soldiers during the Vietnam War in order to gain new contracts and markets. South Vietnam was initially the largest recipient of Korean heavy industry products. Thanks to the 
involvement in French Indo-China, Koreans also gained wider access to the American market, from which they effectively benefited.

The Korean model fits into the wider context of economic changes known as the East Asian model. The transformation process shows many similarities with the experience of Japan and Taiwan. The common features of this model include: high investment ratio, low share of the public sector, supporting export, creating conditions for strong competition in the labour market (minimised role of pro-employee institutions), state intervention in selected areas (active and invasive economic policy) (Kuznets, 1988, p. 17). The size of the state sector is not directly related to economic growth, but is indirectly linked with governmental expenditure and investment. Korean economic development was based on increasing industrial production designated for export and improving the financial situation of farmers (Chung-yum, 2011, p. 187). It all began in the early 1960s with simple, imported assembly lines. Initially, Korean industrial products and processes were imitations of their Japanese equivalents.

The pro-export policy was adopted in the mid-1960s as the main economic strategy and consistently implemented over the next decades. It was characterised by a number of factors: protectionism, anti-import policy, subsidising exporters and state aid (creation of investment areas for enterprises to undertake export activities).

The export policy allowed businesses to obtain foreign currencies, while the competition on the international market led to continuous work on improving quality. Import was allowed, but only if it aided further export. Export production enabled economies of scale, which would have been impossible in the case of production solely for the internal market, as well as development of technology and the ability to compete in the international market (Keesing, 1967). Initially, this policy caused many inconveniences. Car prices in Korea rose so high that they were double those that prevailed abroad (Lee, 2011). Today, Korea holds the fifth place in the world in car production.

The promotion of Korean products abroad took on the form of a systematic process, which included full state support - trade missions, service, contacts. The foreign exchange policy aimed at increasing exporters' income and was thus also an export-oriented instrument (Kuznets, 1988, p. 30). Increasing revenues through exports allowed for well imports and increased the creditinvestment capacity, which in turn, contributed to the increase in production (Kuznets, 1985, pp. 62-32). 
However, the development of Korea would not be possible without FDI. ${ }^{9}$ The Korean government's approach to creating an investment space available for foreign companies was extremely selective. Investments in sectors manufacturing mass products for the internal market were blocked. Only those investors were accepted who allowed for acquisition of technologies, processes and management culture. The desired legal form of the foreign investor's presence in Korea was a joint venture, which meant that in each case, a Korean partner who could not only participate in the management, but would eventually take over control of the technology, was involved.

The economic transformation caused the share of agriculture in the Korean GNP to fall from 37.5\% to 3.5\% (Mahlich and Pascha, 2012), p. 65). Park Chung Hee introduced an economic policy in opposition to the free market: numerous subsidies, planning, strong administrative interventionism in the production process, market protection and nationalisation of banks. Out of the three Asian tigers - Japan, Taiwan and Korea — the third one is considered the economy with the most extensive interventionism (Kuznets, 1988, p. 32). According to Peter Evans (1985, pp. 85-86), the efficient administrative apparatus could be more important than even raw materials or capital.

The financial sector was the key to making an effective impact on the market. The nationalised banking sector became the basic tool for controlling private entities involved in Korean industrial development (Kightley, 2013). Special investment financing instruments were established, such as the National Investment Fund in 1973 and institutions supporting export such as the Korea Trade Promotion Corporation (1962), public-private associations-Korea International Trade Association (1969), Export Information Centre and the Export Idea Bank. The state also controlled Chaebols - huge trans-sectoral enterprises managed mainly by their founding families - by providing them access to attractive financial instruments. ${ }^{10}$

The 1993 World Bank Report was planned as a study of the theory of development, but became instead the weapon of neoliberal orthodoxy, according to which the central role of the free

\footnotetext{
${ }^{9} \mathrm{FDI}$ - foreign direct investment.

${ }^{10}$ Chaebols are regarded almost a symbol of the Korean economic system. In the past, they were derived from small, private enterprises. Thanks to the government's policy (loans, subsidies, economic planning), they have gained even greater significance in the Korean economy. They have now taken the form of large conglomerates. Chaebols constitute a closed production structure, avoiding external subcontracting. Within the framework of the consolidation of the production branches, they have departed from wide production and specialized in specific industries. The biggest chaebols (the superchaebols) are Hyundai, LG Group and Samsung.
} 
market was the basis for development. The critics of the report accused it of excessive simplification and erroneous separation of market mechanisms from the institutions referred to in the report (Gilpin, 2001, p. 325).

The causes of economic development should be budgetary discipline, low increase in wages $^{11}$ large expenditure on education, opening up to foreign technologies and exchange of goods. In line with this neoclassical economics theory, Korea developed not because of state intervention in the economy, but despite it (Kightley, 2013, p. 13). According to D. Hundt, however, the neoclassical paradigm does not have either the conceptual apparatus, nor an appropriate research approach, for analysing the large-scale participation of the state, and the nation as a community, in creating the economic reality (Hundt, 2009, p. 23).

According to Peter B. Evans (1995) and Dani Rodric (1994), Korea is an example of the most advanced and most ambitious economic planning in the capitalist system. They have appreciated the role of administration, planning, limiting the free market rules, and strong state intervention. The state becomes the initiator, sets directions for development, and also has all the instruments of resource allocation.

From the theoretical point of view, a fully free market (lack of coordination) can lead to a trap, which prevents an economy from moving beyond a certain development threshold. The neoclassical assumption, with its focus on macroeconomic stability, high savings rate, technological progress, and development of human capital, may not be sufficient without proper coordination. In economies with a low development level, entrepreneurs face many obstacles such as low rate of capital accumulation, and a market limited from the quantitative and qualitative point of view. Their investment decisions are burdened with higher risk, which means that they try to avoid long-term investments and those involving more capital.

The Koreans treated the Ricardian assumptions of comparative advantage as dynamic variables that could be shaped by conscious economic policy. ${ }^{12}$ Thus, the country with agrarian monoculture, whose production capacity did not go beyond the sale of basic agricultural products, has become one of the largest producers of modern, highly processed products from the high-tech sector.

\footnotetext{
${ }^{11}$ Low income also means low consumption as well as the opportunity to accumulate capital and increase savings.

${ }^{12}$ M. Kightley, op. cit., p. 10.
} 
Korean versatility in economic planning is apparent in many areas: taxes, monetary policy, trade, investment management, agriculture, industry, labour market, free market and shaping prices, energy. ${ }^{13}$ Interventionism in Korea was implemented as part of 5-year plans, and from 1980, in the medium-term fiscal plans' perspective. Planning, budgeting and evaluation were conducted by the EBP (Economic Planning Board) established in 1963, whose chairman was the serving deputy prime minister. The Council indicated the priority sectors which, in its opinion, showed the greatest development opportunities. The president monitored activities within the framework of the largest projects (Shinohara, Yanagihara and Suk Kim, 1983). The support of the Korean state to selected sectors included mainly preferential lending, subsidies, tax reliefs or protection against foreign competition. The national brands were actively and consistently promoted (Kędzierski, 2013, p.3). However, it is not planning that is considered to be the strongest feature of state interference, but extremely efficient implementation, which distinguishes Korea from other countries (Mason, 1980, pp. 66-69).

The state, preparing the economy for development, also created appropriate legal and formal conditions. During the period 1967-1969, a number of legislative solutions addressing particular branches of industry were prepared. They regulated the rules of using state aid and applying for preferential financing instruments and indicated strategic products for which special support would be available (the list included semiconductors and computers). In 1973, Park announced the beginning of the next stage of transformation: construction of heavy and chemical industries. The following industries could count on receving special privileges: shipbuilding, steel, chemical (built from scratch), machine (car), electronics and metal. The implementation of the plan was supervised by the Council. During period 1977-1979, 80\% of all industrial investments were concentrated in the indicated areas. In the 1980s, the Korean government reduced the scale of interventionism due to excess investment, the scale of the Korean economy; growing inflationary pressure and increased debt levels, the Korean industry's proven ability to compete on the global market, as well as the rise to power of economists educated in the US and related to the new president, Chun Doo Hwan (Kędzierski, 2013).

\footnotetext{
${ }^{13}$ Study issued by the federation of the largest Korean enterprises. Koo Cha-kyung (1987) Korea's Economic Policies. Seoul: The Federation of Korean Industries .
} 
The driving force of Korean development — high production capacities and economies of scale-were supported by the development of modern technologies, which helped Korea to significantly increase the added value produced in its economy. The whole process was obviously moderated and supported by the government. ${ }^{14}$ The share of the IT industry in Korean exports increased during1989-2010 from USD 7 billion to USD 126 billion (Kędzierski, 2013, p. 9).

Without any doubt, there would be no Korean 'miracle' without a phenomenal, long-term committment to the idea of supporting development systems for public education. The most important element of building the economy was a conscious education policy, the aim of which was to educate qualified staff capable of taking on challenges related to development. The simultaneous complementarity and completeness of the education system has made it possible to create an offer for laboratory scientists, engineers, and skilled workers.

A number of initiatives have been taken to cultivate a motivated, committed, and strong new employee class. The initiatives were aimed at increasing their 'quality' and motivation, hence it was deemed necessary to create appropriate conditions for citizens. The starting point was the housing construction programme for the newly created city class, strongly supported by government investments. Investments also maintained high standards of municipal and health services, as well as education.

The belief in the Korean economic 'miracle' was shaken only by the great Asian crisis of 1997. Of course, its causes should also be sought in external conditions. The most significant internal, structural weaknesses that contributed to the crisis were the underdeveloped financial system, the rigid labour market and the high level of debt that had been incurred by enterprises (Park and Rhee, 1998). Problems occurred due to microeconomic weaknesses and macroeconomic management instability. The crisis exit plan imposed by the IMF included: financial liberalisation, restructuring of enterprises, privatisation, and a more flexible labour market. Interestingly, the effect of this policy was the reduction of GDP by $6.9 \%$ in 1998. Even the bastion of neoliberalism, the IMF, allowed the Korean government to use Keynesian instruments, including the reconstruction of complex mechanisms of supervision over the financial market (Yong-Chool Ha and Wang Hwi Lee, 2007, p. 897). Structural changes, however, have been introduced, which

\footnotetext{
14 E.g. Computer Networks Promotion Program (1985) National Information Basics Program (1987), Cyber Korea
} (1999-2002). 
permanently reduced the government's influence on the banking system and the enterprises sector. State intervention was limited to market mechanisms. The manifestation of liberalisation was also the opening to international competition, which was symbolised by the signing of free trade zone agreements. Post-crisis reforms have brought the Korean economy from the East Asian to the Anglo-American model, although it has preserved its specificity, especially in the area of the structure of enterprises (Yong-Chool Ha and Wang Hwi Lee, 2007, pp. 913-914).

According to the IMF data for 2016, Korean GDP at constant prices amounted to USD 1.411 trillion (for comparison, Poland GDP amounted to USD 469 billion), PPP GDP (according to the purchasing power parity) of Korea amounted to USD 1.933 trillion (whereas that of Poland, to USD 1.051 trillion). Calculated per capita, PPP GDP of Korea amounted to USD 37.730 (whereas that of Poland, to USD 27,690). The turnover balance was closed with the surplus of USD 98 billion, which is as much as 7\% of GDP (in Poland, 0.95 billion and0.2\% of GDP, respectively). In 2016, investments in Korea amounted to as much as $29 \%$ of GDP (whereas in Poland the figure was $19.6 \%$ of GDP) and the savings rate was $36 \%$ of GDP (whereas in Poland it was $19.6 \%) .{ }^{15}$ Economic growth has not brought with it high economic diversification of Korean society (Chenery, 1974).

The strength of the Korean economy can be proved by the fact that the two richest, largest and most innovative markets in the world have decided to launch economic integration. In March 2012, the free trade agreement between the USA and Korea (the KORUS FTA) entered into force (Choi, 2015). The European Union also decided to create a free trade zone with Korea. The manifestation of the strong presence and power of the Korean economy in Europe is reflected in the fact that half of the Korean cars sold in Europe are produced in the Czech Republic and Slovakia (Kang, 2017).

\section{Economic transformation in Poland}

At the end of the 1980s, it was obvious to everyone that it was no longer possible to maintain the communist system. The Polish People's Republic needed a systemic transformation—not an easy task. As the eminent economist Janos Kornai (1992, p. 360) wrote: '...the key to explaining the classical communist system is the political structure. Its starting point

\footnotetext{
${ }^{15}$ According tp WEO IMF, data for 2016.
} 
is the indivisible power of the ruling party, the mutual penetration of the party and the state, as well as the prohibition of activity of any forces that are not fully consistent with the party's policy or even contradictory to it'. In the communist era, everything was political, and the state was a highly hierarchical structure controlled by the party organisation. As late as in 1985, the state sector included $81.7 \%$ of national production and $71.5 \%$ of total employment (in the Soviet Union, as much as $96 \%$ of production came from state-owned enterprises) (Lipton, Sachs and Summers, 1990, p. 300).

Apart from Hungary, Poland was one country attempting to implement some liberalisation measures in trade with the West before the transformation. In Poland, since 1972, more marketoriented mechanisms of goods valuation were introduced, which constituted a deviation from the policy of centrally determined prices. There were also limited attempts to restrict the state's monopoly in international trade, which was embodied by foreign trade centres (e.g. Universal, Pewex, Baltona). The first bill on economic activity was introduced in Poland in December 1988 (the Wilczek Bill) and it legalised private business activity and was based on the free-market principle 'what is not prohibited is allowed'.

The Beginning of Economic Reform

The first comprehensive reform proposal was presented in Poland in 1988. ${ }^{16}$ Leszek Balcerowicz is considered the key figure behind economic change in Poland. The goal of the group he created was a complete break with market socialism and the introduction of the market economy. Its main belief was that reform must be radical and immediate. In May 1989, Balcerowicz conceived of a short reform programme that aimed at privatisation, trade liberalisation, exchangeability of the currency, and an open economy. The Balcerowicz Program has become a symbol of radical, comprehensive reform and a model for change in other countries undergoing transformation, including Russia, Czechoslovakia, Romania and Bulgaria. The presentation of doctrinal inspirations, the content of the programme and the plan of its implementation are not difficult to understand. The plan consisted of 11 bills passed on 27 December 1989 and signed by President Jaruzelski on 31 January 1990.

16 See M.Dąbrowski, S. Kawalec, J. Lewandowski, J. Szomurk, J. Beksiak, R. Bugaj (1989) Propozycje przeksztatcenia polskiej gospodarki (Proposals for transforming Polish economy). Warszawa: PTE. 
The transformation plan came from neoliberal circles centred around the International Monetary Fund. The conceptual and theoretical background for the shock therapy constitute the neoliberal economic programme expressed in ten points in the Washington Consensus, the achievements of the Chicago Monetary School and new classical economics (Lavigne, 1999, p. 237). Shock therapy means making as many changes as possible in the shortest period of time. The task of preparing the financial stabilisation reform was entrusted to Jeffrey Sachs and David Lipton. It can be seen that the idea for Polish transformation came from outside Poland. ${ }^{17}$

The construction of capitalism in the former COMECON countries was perceived as a process involving four key stages: the first included the release of prices from state control, which was to be the foundation of the market's self-regulation. The natural consequence of this was marketisation of the prices, which meant their rapid increase. Second was the reduction of inflation using all possible means. Third was the creation of a professional mechanism for managing enterprises, which was not possible under the conditions of state ownership. Hence, privatisation, carried out on a large scale, became necessary. Finally, anticipating the deep social transformations, social security mechanisms had to be created (Aslund, 2010, p. 51).

The Balcerowicz Program

The Balcerowicz Program focused on macroeconomic stabilisation, radical deregulation and integration with the global economy. Convertibility of the Zloty and privatisation were started (Slay, 1993, p. 237). As early as in January 1990, prices were liberalised, the economy was opened to international trade, state-owned corporations and conglomerates were broken up, thanks to which independent enterprises emerged; and as it seems, the most important legal regulation of the freedom of economic activity was established (Aslud, 2010, p. 114). Monetary policy was tightened: the money supply was reduced and interest rates were adjusted. Banks were given independence in determining interest rates on loans and deposits. By limiting expenditures, subsidies and public support, high fiscal discipline was sought. Urban squares swarmed with merchants, traders and small bisnesses. From then on, without the need for administrative approval, everyone could offer products anywhere at any price.

Liberalisation in Poland was designed to bring economic freedom, allowing ordinary people to trade and to set prices. It caused the transition from a shortage of goods and services

\footnotetext{
${ }^{17}$ See Interview with S. Ciosek in TVP (Polish National TV) on 25.02.2016.
} 
situation to one where money became a scarce good. This led to the transition from the producer's economy to the consumer's economy. The market was opened for foreign commodities. In 1990, the new average ad valorem duty for industrial products was reduced to 12\% (Marer, 1991).

The free market also entails legal and administrative regimes unknown to the communist countries. Transformation took place without transparent regulations. New civil law solutions had to be created as there was no comprehensive, modern commercial code, nor any regulations regarding the financial and capital market. It was necessary to pass basic economic regulations as well as adopt efficient mechanisms regulating debt issues. A free market economy cannot be introduced where the integrity of the full scope of private property rights is not guaranteed.

The release of prices from control had many consequences: it led to the elimination of price subsidies and created conditions for balancing the budget. It was also necessary to limit direct subsidies to state-owned enterprises (in 1990, subsidies for such enterprises still exceeded 7\% of GDP) ${ }^{18}$ Hyperinflation turned out to be a big problem, whose eradication became a priority. ${ }^{19}$ It was necessary to introduce fiscal discipline and a new tax policy. The next step was the tightening of the monetary policy regime. An important element constituted the determination of a single exchange rate and the creation of mechanisms that could ensure the independence of the central bank. Changes had to be brought to ensure the minister of finance was always the deputy prime minister. The remnant of communism was the high share of state expenditure in the GDP - around $50 \%$. The standard rate of central redistribution is estimated at approximately $15-25 \%$ of GDP. ${ }^{20}$ The share of state budget expenditure in GDP in 2017 amounted to $19.6 \%$.compared to 19.8\% in 2016 (Cieślak-Wróblewska, 2017).

In the course of the transformation, money gained real value. The authors of the reform programme set three main tasks for the monetary policy: strengthening of the central bank, subjecting money emission to strict discipline, and transitioning from administrative to market tools. Loose policies were replaced by rigorous measures.

In January 1990, Poland introduced the convertibility of its currency on the current account of its balance of payments. Determining the exchange rate of the Zloty against the dollar was

\footnotetext{
${ }^{18}$ European Bank for Recontstruction and Development, Transition Report 1997, London 1997.

${ }^{19}$ The symbol of the fight against inflation was the tax on excessive wage increases, the popiwek.

${ }^{20}$ For comparison: the Czech Republick 12\%, USA 13\%, Great Britain 13\%, Italy 27\%, South Korea 25\%, France $30 \%$, OECD average - 23,6\%. [Online] Available from: https://data.oecd.org/gga/central-governmentspending.htm\#indicator-chart [accessed 01.10.2018].
} 
considered a transitional solution, and in May 1991, a devaluation was necessary. Later, the 'creeping devaluation' system was adopted, trying to keep the exchange rate within the limits modified, as needed. Interestingly, this policy was widely approved and Poland managed to achieve financial stability while avoiding an overvalued exchange rate. This solution is considered an example of successful departure from a fixed exchange rate (Fisher and Sahay, 2000).

Privatisation following the ending of a communist system, as happened in Poland and its neighbours, is unprecedented in history. Over one decade, more than 150,000 large and small enterprises, hundreds of thousands of small businesses and real properties were privatised in transition countries (Djunkov and Murrell, 2002). The communist economy with an almost nonexistent private sector managed to create a mechanism based on market regulations that restored private ownership and initiative in manufacturing processes. The main goal of privatisation was to achieve a clear separation between the state and business enterprises. It was not only of economic, but also of political character. Most important, however, was the creation of conditions for the emergence of a market economy based on private ownership.

There were several models for the privatisation process: the original public offer (sale of shares to investors and their introduction to trading on stock exchange), direct sales or investment offer (sale to an investor, usually foreign), coupon privatisation (mass privatisation with the emission of public vouchers distributed practically among the whole society), transfer of the enterprise to its management and staff (enfranchisement of employees in relation to the company's assets, the simplest form in terms of administration), bankruptcy and liquidation (effecting bankruptcy, liquidation and sale of assets under market conditions) (Aslund, 2010, pp. 195-205).

Advisors of Balcerowicz argued for the fastest possible privatisation based on the commercialisation of enterprises and the distribution of their property to a wide range of recipients: private, institutional, and even social groups (Lipton, Sachs and Summers, 1990, p. 333). Privatisation based on an investment offer is time-consuming, not very transparent and requires the existence of a properly functioning administration. In Poland, practically all forms of privatisation were applied. Liquidation by bankruptcy has become the main method of privatising medium-sized enterprises.

The issue of privatisation is highly controversial. Despite all allegations, it cannot be denied that a lasting transformation of Polish economy took place due to privatisation. The relationship between the privatisation process and production is clear- technology is transferred, real corporate 
governance and professional, effective production management are introduced, the drastic impact of politics on the economy is reduced. In terms of the political dimension, the market economy and democratic mechanisms are established. The scale and pace of privatisation in Poland were the outcome of the overall conviction that the resulting social and other costs and losses would be lower than if the status quo were to be maintained or if the process of change were to be extended over a longer period (Lipton, Sachs and Summers, 1990, p. 297).

Table 2: Poland's and Korean Republic's GDP per capita 1980-2017 measured in PPP. Own study. Source: WEO IMF.

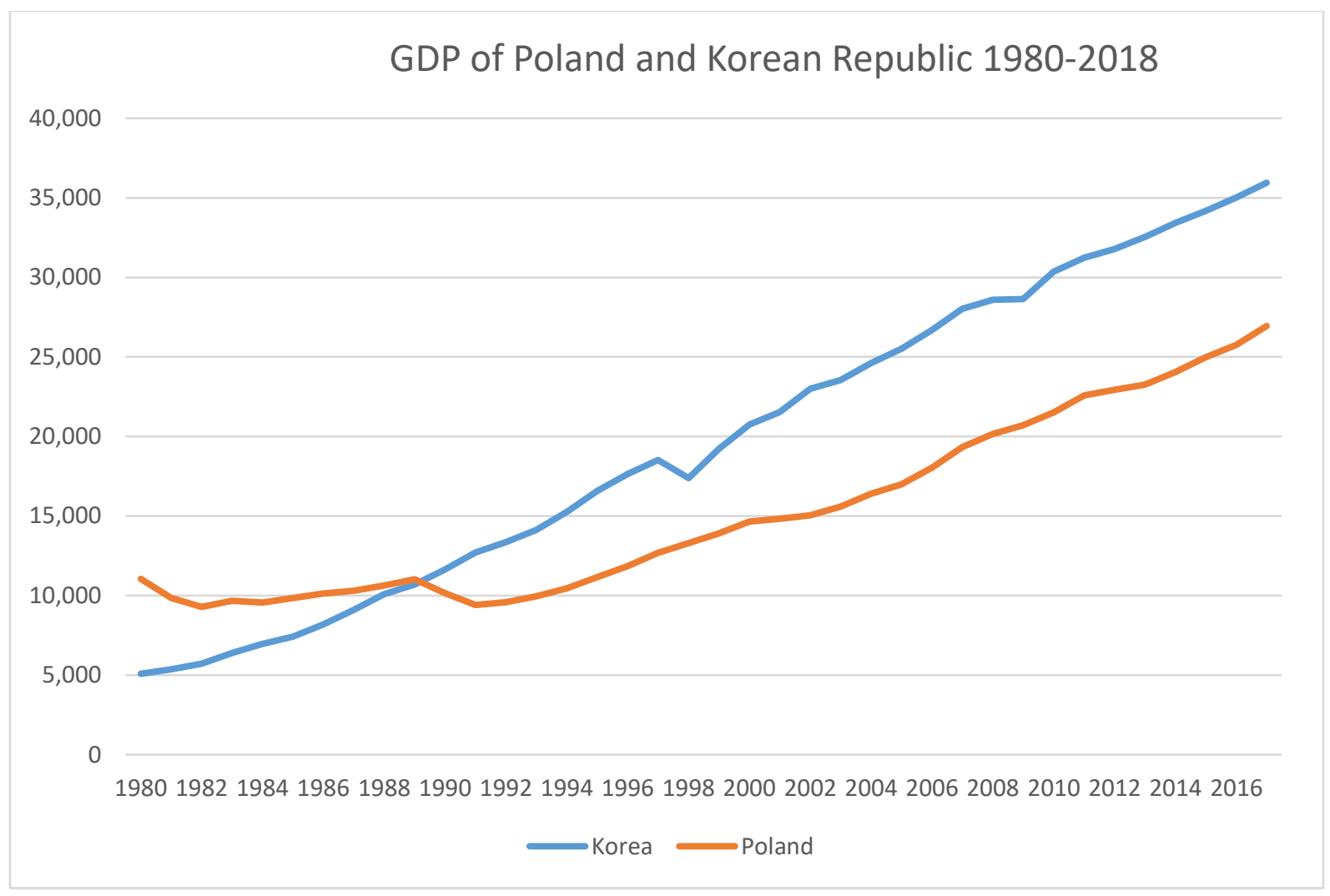

The issue of transformation, goals and methods of implementation is also extremely controversial (Prowse, 1992). The first disappointments came in the early 1990s. The criticism of reforms was based on the Washington Consensus, especially after the results they brought in Central and Eastern Europe (Stiglitz, 2002). There were also claims that despite recognition of the transformation's imperfections, it is difficult to conclude that another transformation model would be more effective (Slay, 1993, p. 252). 


\section{Summary}

The Korean model of economic development, a derivative of the deterministic approach, contains the Asian vision of socio-economic reality that involves collective values and hierarchy. The whole Korean development plan was part of a long-term, coherent strategy with clearly defined goals. The basis for the chosen development model was the strong and active role of the state, which translated into greater interventionism.

The example of Polish transformation constitutes the result of the application of Washington Consensus assumptions: classical economics with the dominating role of the independent, resourceful, and egoistic individual-homo oeconomicus, monetarism with the key issue of quantitative theory of money and inflation as well as broadly understood neoliberalism with its admiration for the extremely free market. Poland has become a testing ground for a vision that was doctrinal in its assumptions. Major achievements and results of both countries are presented in Table 3 .

Table 3 Selected macroeconomic indicators for Poland and South Koreain 2017. * data for 2016 ** data for 2015. Source: WEO IMF. Own study.

\begin{tabular}{|c|c|c|}
\hline Indicator & Poland & Korea \\
\hline Population & 38 million & 51 million \\
\hline $\begin{array}{l}\text { GDP in USD } \\
\text { (official exchange rate) }\end{array}$ & $524 \mathrm{~b}$. & $1538 \mathrm{~b}$. \\
\hline $\begin{array}{r}\text { PGDP per capita, } \\
\text { PPP in } \mathrm{USD}^{21}\end{array}$ & 26,889 & 35,918 \\
\hline $\begin{array}{ll}\text { Investments in } \% \\
\text { GDPB }\end{array}$ & $19,95 \%$ & $31 \%$ \\
\hline Savingsin \% GDP & $20 \%$ & $36 \%$ \\
\hline
\end{tabular}

\footnotetext{
${ }^{21} \mathrm{PPP}$ index (purchasing power parity) is an indicator taking into account the purchasing power of money. According to the official exchange rate, Poland's GDP in 2017 was USD 540 billion and according to PPP it equals USD 1.08 trillion.It means that our economy, despite the fact that it produces athe value of USD 540 billion, under our specific conditions, can acquire goods and services as if it had the value of USD 1.08 trillion. This situation can be easily explained by way of example: we can buy more for USD 100 inside Poland than in the United States.
} 


\begin{tabular}{|c|c|c|}
\hline $\begin{array}{c}\text { Current account } \\
\text { balance in \% GDP }\end{array}$ & $+5,1 \%$ & $+0,04 \%$ \\
\hline $\begin{array}{r}\text { Goods and services } \\
\text { export in USD* }\end{array}$ & $251 \mathrm{~b}$. & $586 \mathrm{~b}$. \\
\hline $\begin{array}{l}\text { Number of patent } \\
\text { applications submitted } \\
(\mathbf{2 0 1 5}) * *\end{array}$ & 4815 & 213694 \\
\hline
\end{tabular}

Summarising the whole research and taking into account the results obtained, the author would like to present the final comparative analysis using table 3 below:

Table3. Own study.

\begin{tabular}{|c|c|c|}
\hline & South Korea & Poland \\
\hline $\begin{array}{l}\text { Programme } \\
\text { references }\end{array}$ & Southern Consensus & $\begin{array}{l}\text { Washington } \\
\text { Consensus }\end{array}$ \\
\hline $\begin{array}{l}\text { Approach to } \\
\text { economic development } \\
\text { rules }\end{array}$ & Deterministic & $\begin{array}{l}\text { Universal } \\
\text { (structural) }\end{array}$ \\
\hline $\begin{array}{l}\text { Form } \\
\text { capitalism }\end{array}$ & State capitalism & Market capitalism \\
\hline $\begin{array}{l}\text { Introduction of } \\
\text { reforms }\end{array}$ & Gradualism & Shock therapy \\
\hline Trade exchange & Protectionist practices & Free trade \\
\hline Economic policy & Industrial policy & $\begin{array}{l}\text { Lack of industrial } \\
\text { policy }\end{array}$ \\
\hline Market model & Interventionist model & Liberal model \\
\hline Banking sector & $\begin{array}{l}\text { Dominance of state } \\
\text { ownership }\end{array}$ & $\begin{array}{l}\text { Dominance of } \\
\text { private ownership }\end{array}$ \\
\hline $\begin{array}{l}\text { Foreign } \\
\text { investments }\end{array}$ & $\begin{array}{l}\text { FDI selectively approved by } \\
\text { the government }\end{array}$ & $\begin{array}{l}\text { Lack of restrictions } \\
\text { regarding FDI }\end{array}$ \\
\hline
\end{tabular}




\begin{tabular}{c|r|r|r|}
\multicolumn{1}{c|}{$\begin{array}{c}\text { Planning state } \\
\text { economy }\end{array}$} & $\begin{array}{c}\text { Planning and Focus on } \\
\text { strategic branches }\end{array}$ & Lack of planning \\
\hline \multicolumn{2}{|c|}{ Role of domestic } & Concentration of domestic & Lack of mechanisms \\
capital & capital-including traditional for & concentration of \\
& family businesses (chaebols) & domestic capital
\end{tabular}

Despite the differences, the Korean and Polish models of development are characterised by essential common elements. These include: the sanctioning of private property as the basis of the socio-economic order, the free market as an instrument for the allocation of goods and resources, the dominance of the private sector and low participation of the public sector in the economy as well as a labour market favourable to the employer.

Answering the questions asked in the introduction, it would be advisable, while maintaining the adopted assumptions, to recognise that models of transformation are characteristic for the adopted theoretical paradigms-liberal and interventionist. It must be remembered, however, that they have changed over time. When it comes to the question which model is more effective, the answer is more difficult. Due to the differences in the longevity of the changes, the assessment of development levels today would be unfair. So for instance, it would be more appropriate to compare Poland in 2016 with Korea in 1988 (see Table 2). In view of these difficulties, the more interesting should be the history of the IDEA for economic development which actually created 'from scratch' not only general prosperity and the modern state, but also gave life to innovative giants such as Hyundai, LG and Samsung. These most recognisable Korean brands are starting to shape both the future of Korea and the entire global market.

Certainly, this is an interesting lesson for any country which, after achieving its first economic successes, begins to dream about climbing innovation charts, abandoning low-income production structures and increasing its share in the added value of global production chains. Going to final conlusion. There is no doctrine or any universal theory that can answer for all questions and replace thinking, educated people. Both transformations can give good material to study and learn. 


\section{References}

1. Acemoglu D., Introduction to Modern Economic Growth. Princeton University, Princetown 2008.

2. Acemoglu D., Robinson J., Why Nations Fail. Penguin Random House, New York 2012.

3. Amin S., Unequal Development Monthly Review, New York 1976.

4. Amsden A., Asia’s Next Giant. New York: Oxford University Press 1989.

5. Bhagwati J., Panagariya A., Why Growth Matters: How Economic Growth in India Reduced Poverty and the Lessons for Other Developing Countries. Public Affairs 2013.

6. Bożyk P., Apokalipsa według Pawła. Jak zniszczono nasz kraj (Apocalypse according to Paul- How our country was destroyed in Poland) Wrocław: Wydawnictwo WEKTORY 2015. 7. Chenery H., Redistribution with Growth. London, Oxford: Oxford University Press. Interestingly 1974.

8. Clifford M.L., Troubled Tiger: busiessmen, bureaucrats, and generals in South Korea. New York:An East Gate Book 1998.

9. Cypher M., J.L. Dietz The Process of Economic Development. London: Routledge, 1997.

10. Dąbrowski M.,, Kawalec S., Lewandowski J. Szomurk J., Beksiak J., Bugaj R., Propozycje przekształcenia polskiej gospodarki (Proposals for transforming Polish economy). Warszawa: PTE 1989.

11. S. Djunkov, P. Murrell, Enterprise Restructuring in Transition, A Quantitive Survey in Journal of Economic Literature, vol. 40, issue 3, 2002.

12. Dos Santos T., The Structure of Dependency. American Economic Review no.60, 1970.

13. P. Evans, Embedded autonomy: states and industrial transformation. Princeton: Princeton University Press 1995.

14. Fisher S., Sahay R., The Transition Economies after Ten Years. In International Monetary Fund Working Paper no. 30, 2000.

15. Frank A.G., Capitalism and Underdevelopment in Latin America. Monthly Review Press, New York 1967.

16. Gerschenkron A., Economic Backwardness in Historical Perspective. Cambridge, Mass.: Harvard University Press 1962. 
17. Gilpin R. Global Political Economy-Understanding the International Economic Order. Princeton: Princeton University Press 2001.

18. Gołota Ł., Washington Consensus - przewartościowanie i upadek neoliberalnego paradygmatu(Washington Consensus - revaluation and collapse of the neoliberal paradigm), in Tendencje i procesy rozwojowe współczesnych stosunków międzynarodowych. Księga jubileuszowa $\mathrm{z}$ okazji 40-lecia Instytutu Stosunków Międzynarodowych Uniwersytetu Warszawskiego, (Trends and development processes of contemporary international relations. A jubilee book celebrating the 40th anniversary of the Institute of International Relations at the University of Warsaw), Warszawa 2016.

19. Krugman P., Development, Geography, and Economic Theory.Cambrige: MIT Press 1995.

20. Gołota Ł., Teoria handlu międzynarodowego Johna Stuarta Milla. (The theory of international trade of John Stuart Mill.). Stosunki Międzynarodowe, Vol. 52 no. 2. 2016.

21. Hundt D., Korea's development Alliance: state, capital and politics of rapid development. New York: Routledge 2009.,

22. Jarmołowicz W., Piątek D., Polska transformacja gosodarcza - przesłanki, przebieg, rezultaty. (Polish economic transformation—premises, implementation, results.[Online], 2016.

23. Johnson C., MITI and the Japanese Miracle - The Growth of Industrial Policy, 1925-1975. Stanford: Stanford University Press 1982.

24. Kang K., Ramachandran V., Economic Transformation in Korea: Rapid Growth without an Agricultural Revolution?, in Economic Development and Cultural Change, The University of Chicago Press Vol. 47, No.4 (July), 1999.

25. Keesing D.B., Outward-looking Policies and Economic Development. Economic Journal 77, July 1967.

26. Kędzierski M., Industrializacja Korei Południowej - co Polska może wykorzystać?, Analiza Instytutu Sobieskiego (Industrialization of South Korea - how can Poland benefit?, Analysis of the Sobieski Institute) no. 52, May 2013.

27. Kightley M., Polityka i reformy Park Chung Hee jako źródło gospodarczego skoku Korei Południowej, Oficyna SGH, 2013.

28. Kim Chung-yum, From Despair to Hope. Economic Policymaking in Korea 1945-1979, Seoul: Korean Development Institute 2011. 
29. Klein L., Pomer M., The new Russia: Transition Gone Away, Stanford: Stanford University Press 2001. 2001: P. Bożyk (2015) Apokalipsa według Pawła. Jak zniszczono nasz kraj (Apocalypse according to Paul- How our country was destroyed) Wrocław: Wydawnictwo WEKTORY.

30. Kuznets P.W., An East Asian Model of Economic Development: Japan, Taiwan, and South Korea. Economic Development and Cultural Change, Vol. 36, No.3. Supplement: Why Does Overcrowded, Resources-Poor East Asia Succeed: Lessons for the LDCs?, April, 1998.

31. Kornai J., The Socialist System - The Political Economy of Communism. Princeton, New York: Princeton University Press 1992.

32. Kuznets P.W., Government and Economic Strategy in Contemporary South Korea. Pacific Affair, Spring 1985.

33. Kuznets P.W., An East Asian Model of Economic Development, Economic Development and Cultural Change, Vol. 36, No.3. Supplement. April 1988.

34. Marer P., Foreign Economic Liberalization in Hungary and Poland. The American Economic Review, Vol. 81, No. 2, May 1991.

35. Mason E.S., The Economic and Social Modernization of the Republik of Korea. Cambridge: Harvard University Press 1980.

36. Lee N.Y., The Automobile Industry, in the Park Chung Hee Era. In B.K. Kim, E.F. Vogel (eds.) The Transformationof of South Korea, London: Harvard University Press 2011.

37. Mahlich J., Pascha W., (eds.) Korean Science and Technology in an International Perspective. Berlin, Heidelberg: Springer-Verlag 2012.

38. Lavigne M., The Economics of Transition-From Socialism Economy to Market Economy. London: Macmillan Press, pp. 118-119; Ben Slay (1993) The Dilemmas of Economic Liberalism in Poland. Europe-Asia Studies, No.2 1999.

39. Lipton D., Sachs J., Summers L. H., Privatization in Eastern Europe: The Case of Poland. Brookings Papers on Economic Activity, Vol. 1990.

40. Myrda G., Economic Theory and Underdeveloped Regions. NewYork: Harper Torchbooks, 1957.

41. O’Brien, Williams M..,Global Politcal Economy. New York: Palgrave Macmilan 2013.

42. D. Park D., Rhee C., Currency Crisis in Korea: How Was It Aggravated? Asian Development Review 16(1) 1998. 
24. Piątek D., Szarzec K. Liberalna koncepcja jednostki gospodarującej i jej implikacje dla transformacji gospodarczej (The liberal concept of the economic unit and its implications for economic transformation). In W. Jarmołowicz, M. Ratajczak (eds.) Liberalizm we współczesnej gospodarce (Liberalism in the contemporary economy). Poznań: Wydawnictwo Akademii Ekonomicznej w Poznaniu 2008.

25. Ricardo D., On the principles of Political Economy and Taxation. In The works and correspondence of David Ricardo, Vol. 1, Liberty Fund, IncIndianapolis 2004.

26. Rodrik D., Economics Rules: The Rights and Wrongs of the Dismal Science. Norton \& Company, Inc., New York 2015.

27. Rosenstein-Rodan P.N. Problems of Industrialization of Eastern and South-Eastern Europe. Economic Journal no.53, 1943.

28. Rostow W.,The Stages of Economic Growth. Cambridge: Cambridge University Press 1960.

29. Samuelson P., Foundations of Economic Analysis. Cambridge, Mass.: Harvard University Press, 1983.

30. Shinohara M., Yanagihara T., Suk Kim K., The Japanese and Korean Experience in Managing Development. Washington: World Bank Working Paper no. 574,1983.

31. Slay B.,The Dilemmas of Economic Liberalism in Poland, Europe-Asia Studies, No.2, 1993.

32. Stiglitz J., Greenwald B., Creating a learning society: a new approach to growth, development, and social progress. Columbia: Columbia University Press 2015.

33. Stiglitz J., Globalization and Its Discontent. New York: Norton; S. Cohen (2000) Failed Crusade: America and the tragedy of Communist Russia, New York-London 2002.

34. Wade R., Governing the market - Economic Theory and the Role of Government in East Asian Industrialization, Princeton University Press, Princeton 2003.

35. M. Weidenbaum, The use of social science research in the federal administration. Paper presented at Conference on Social Science and National Policy, Rutgers University 1969.

36. Williamson J., Latin American Adjustment: How Much Has Happened. Washington DC: Institute for International Economics 1990.

37. Wróbel A.,) Paula Prebischa wizja gospodarki światowej i jego rola w rozwoju teorii wymiany międzynarodowej (Paul Prebisch's vision of the global economy and its role in the 
development of international exchange theory). In: R. Kuźniar (eds.) Porządek międzynarodowy u progu XXI wieku. Wizje, koncepcje, paradygmaty (International order at the beginning of the 21st century-Visions, concepts, paradigms), Uniwersytet Warzawski, Warszawa, 2005.

38. Wziątek-Kubiak A., Kontrowersje wokół proeksportowej strategii rozwoju (Controversies over the export-oriented development strategy), Instytut Nauk Ekonomicznych Polska Akademia Nauk, Warszawa, 1996.

39. Yong-Chool Ha and Wang Hwi Lee, The Politics of Economic Reform in South Korea: Crony Capitalism after Ten Years. Asian Survey, Vol. 47, No.6 (Nov/Dec 2007).

40. Yoo-Duk Kang, Korea-EU FTA: Breaking New Ground. In A. Elijah, D. Kenyon, K.Hussey, Pi. van der Eng (eds.) Australia, the European Union and the New Trade Agenda. ANU Press, Carlton 2017..

41. Youngmi Choi, Ideology, and Economic Interests in U.S. Congressional Voting: The Case of the U.S.-Korea Free Trade Agreement. Political Research Quarterly, Vol. 68, No.2 (June), Sage Publications 2015.

42. Zajączkowski J., Schöttli J., Thapa M., India in the Contemporary World: Polity, Economy and International Relations, New Delhi 2016 